\title{
JPSE
}

(Journal of Physical Science and Engineering)

\section{Pengaruh Nanosilika terhadap Kekerasan dan Porositas Nanokomposit HA-SiO 2 Berbasis Batuan Onyx Bojonegoro}

\begin{tabular}{l}
\hline Received \\
8 October 2016 \\
Revised \\
1 December 2016 \\
Accepted for Publication \\
1 December 2016 \\
Published \\
14 December 2016 \\
\hline
\end{tabular}

\author{
Yudyanto $^{1^{*}}$, Y. D. Sugara ${ }^{2}$ Hartatiek $^{1}$ \\ 1. Jurusan Fisika FMIPA Universitas Negeri Malang \\ 2. Program Studi Fisika Universitas Negeri Malang J1 Semarang 5 Malang \\ *E-mail: yudyanto.fmipa@um.ac.id
}

\begin{abstract}
Hydroxyapatite (HA) is one of bioceramics which used in many biomedic applications. However, HA has poor mechanical properties. HA has be composited with material which has a good mechanical properties, such as nanosilica. In this study, synthesis HA was prepared by co-precipitation method. Base material to synthesis HA is onyx rock from Bojonegoro which contain $94.33 \% \mathrm{Ca}$. While phosphate obtainable from Ammonium Dihydrogen Phosphate. The vickers hardness result using micro hardness vikers show that adding nanosilica is influence the mechanical properties of HA. The value of vikers hardness at adding nanosilica $10,20,30 \%$ respectively are $38.2 ; 42.3 ; 43.1 \mathrm{HVN}$ while the porosity are $44.4 ; 40.7 ; 39.3 \%$.
\end{abstract}

Keywords: nanosilica, $\mathrm{HA}-\mathrm{SiO}_{2}$ nanocomposites, porosity, Vickers Hardness, coprecipitation method

\begin{abstract}
Abstrak
Hidroksiapatit (HA) merupakan biokeramik yang digunakan dalam aplikasi biomedis. Namun, HA memiliki sifat mekanik yang rapuh sehingga HA dikompositkan dengan material yang memiliki sifat mekanik baik yaitu nanosilika. Pada penelitian ini, sintesis HA dilakukan dengan menggunakan metode kopresipitasi. Bahan dasar pembuatan HA adalah batuan onyx Bojonegoro yang dijadikan sebagai sumber Ca dengan kemurnian 94,33\% sedangkan sumber fosfat diperoleh dari Ammonium Dihidrogen Fosfat. Hasil uji kekerasan menggunakan microhardness vikers menunjukkan adanya pengaruh penambahan nanosilika pada kekerasan nanokomposit $\mathrm{HA}-\mathrm{SiO}_{2}$. Besarnya nilai kekerasan untuk masing-masing kadar nanosilika 10, 20, 30\% berturut-turut adalah 38,2; 42,3; $43.1 \mathrm{HVN}$ sedangkan nilai porositasnya adalah 44,$4 ; 40,7 ; 39,3 \%$.

Kata Kunci: nanosilika, nanokomposit hidroksiapatit-SiO $\mathrm{S}_{2}$, porositas, kekerasan, metode kopresipitasi.
\end{abstract}

\section{Pendahuluan}

Dewasa ini perkembangan biomedis untuk perbaikan tulang terus meningkat. Hal ini disebabkan oleh bertambah luasnya pemakaian graft tulang, tidak hanya untuk bahan rehabilitasi tulang tetapi graft juga telah banyak digunakan pada rehabilitasi gigi [4]. Saat ini penggunaan bone graft pada jaringan tulang masih menggunakan autografts dan allografrats. Autografts merupakan bagian tulang yang diperoleh dari bagian tubuh manusia itu sendiri sedangkan allografts merupakan bagian tulang yang diperoleh dari tulang mayat.

Penggunaan kedua bone graft tersebut memiliki banyak kelemahan diantaranya adalah persediaan terbatas, mahal dan berpotensi menularkan penyakit. Oleh karena itu perlu suatu alternatif untuk mengganti graft tulang dengan bahan sintetik yang mempunyai sifat menyerupai tulang asli. Salah satu biomaterial yang dapat dijadikan sebagai bahan dasar rehabilitasi jaringan tulang dan gigi adalah biokeramik.

Biokeramik merupakan bahan keramik biokampoaktibel yang digunakan dalam bidang medis [6]. Salah satu jenis biokeramik yang banyak digunakan karena sifat-sifatnya yang unggul adalah 
hidroksiapatit (HA, Ca10(PO4)6(OH)2). HA merupakan material yang memiliki kesamaan komposisi dan struktur kristal dengan tulang dan gigi [12].

Rekayasa jaringan tulang menggunakan bahan dasar alam menjadi terobosan baru yang sangat menjajikan, mengingat keberadaan sumber daya alam Indonesia sangat melimpah khususnya bahan tambang mineral. Sejauh ini penelitian tentang sintesis HA dilakukan dengan menggunakan batu kapur [7], tulang sotong [14], cangkang telur [5] dan cangkang kerang [11]. Oleh karena itu pada penelitian ini, HA disintesis menggunakan bahan yang belum termanfaatkan kandungannya yaitu batu onyx. Batuan Onyx banyak ditemukan di wilayah Bojonegoro dan Gresik. Batuan Onyx memiliki cadangan yang melimpah, yaitu sekitar $33.750 .000 \mathrm{M}^{3}$ setiap wilayah. Komposisi kimia batuan Onyx yaitu $\mathrm{SiO} 2, \mathrm{CaCO} 3, \mathrm{CaO}$ dan lain-lain. Hasil difraksi sinar-X batu onyx menunjukkan adanya senyawa CaCO3 dengan kemurnian yang tinggi yaitu sebesar 98,23\% [9]. HA memiliki sifat mekanik yang rapuh dalam menahan beban sehingga aplikasi dari HA hanya terbatas pada implan yang tidak sepenuhnya menahan beban. Untuk memenuhi syarat sebagai material substitusi tulang, serbuk HA perlu dikompositkan dengan material yang memiliki sifat mekanik baik. Salah satu bahan yang dapat meningkatkan sifat mekanik suatu material adalah $\mathrm{SiO} 2$.

$\mathrm{SiO} 2$ merupakan salah satu bahan yang melimpah di Indonesia. Keberadaan $\mathrm{SiO} 2$ di alam terdapat pada pasir [10] dan sekam padi. SiO2 memiliki kekuatan mekanik relatif tinggi, koefisien termal ekspansi rendah, dielektrisitas yang baik dan biokompaktibel [2]. $\mathrm{SiO} 2$ berukuran nano memiliki beberapa keunggulan dibandingkan dengan kristal ukuran besar diantaranya kemampuan adhesi yang lebih baik pada banyak subtrat, ketahanan korosi yang tinggi dan ketahanan terhadap retakan [1]. Oleh karena itu, pada penelitian ini HA dikompositkan dengan nanosilika guna meningkatkan sifat mekanik dari HA.

\section{Metode Penelitian}

\subsection{Ekstraksi Raw Material}

Batu onyx digerus mengunakan mortar untuk mendapatkan serbuk. Serbuk diayak menggunakan ayakan 200 mesh dan dikalsinasi pada suhu $500{ }^{\circ} \mathrm{C}$.

\subsection{Sintesis Hidroksiapatit}

Sintesis HA dilakukan dengan menggunakan metode kopresipitasi. Sumber kalsium untuk sintesis HA yaitu batu onyx, sedangkan sumber fosfat diperoleh dari $\mathrm{NH}_{4} \mathrm{H}_{2} \mathrm{PO}_{4}$ Merck 101126. Serbuk onyx ke dalam $\mathrm{HNO}_{3} 2 \mathrm{M}$ dan distirer dengan kecepatan $700 \mathrm{rpm}$ selama 30 menit, selanjutnya ADP ditambahkan ke dalam larutan distirer selama 700 rpm selama 1 jam sambil ditetesi $\mathrm{NH}_{4} \mathrm{OH}$ untuk mengontrol pH 9-10. Hasil yang didapatkan diendapkan selama 24 jam. Endapan dicuci menggunakan DI water dan dikeringkan pada suhu $100{ }^{\circ} \mathrm{C}$ selama 1 jam.

\subsection{Sintesis Nanokomposit $\mathrm{HA}-\mathrm{SiO}_{2}$}

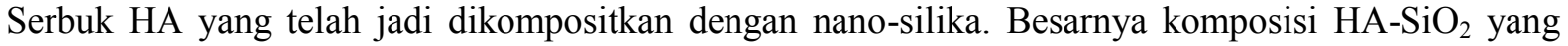
digunakan dalam penelitian ini adalah $90: 10 \%, 80: 20 \%$ dan 70:30\%.

Serbuk HA dimasukkan ke dalam air sebagai media pen-campuran HA dan nanosilika. HA$\mathrm{SiO}_{2}$ distirer dengan kece-patan $1000 \mathrm{rpm}$ selama 3 jam. Selanjutnya, hasil direndam dan disaring untuk menghilangkan kadar airnya. Hasil saring-an dikeringkan pada suhu $100{ }^{\circ} \mathrm{C}$ selama 24 jam.

Nanokomposit $\mathrm{HA}_{-} \mathrm{SiO}_{2}$ dikarakterisasi menggunakan XRD untuk melihat struktur kristal yang terbentuk. Untuk memperoleh ukuran kristal dihitung dengan menggunakan persamaan Schererr.

$$
D=\frac{k \lambda}{B \cos \theta}
$$

dengan $D$ adalah ukuran kristal, $B$ adalah pelebaran intensitas maksimum (FWHM) dalam radian, $k$ adalah konstanta Scherrer bernilai $0,9, \lambda$ adalah panjang gelombang sinar dari radiasi $\mathrm{CuK} \alpha$ yakni $0.154056 \mathrm{~nm}$, dan $\theta$ adalah sudut Bragg. Morfologi $\mathrm{HA}$ dan $\mathrm{HA}-\mathrm{SiO}_{2}$ diamati menggunakan SEM. Perbandingan $\mathrm{Ca} / \mathrm{P}$ dapat dilihat menggunakan EDX.

\subsection{Uji PorositasNanokomposit $\mathrm{HA}-\mathrm{SiO}_{2}$}

Tahap pertama pengujian yaitu komposit $\mathrm{HA}_{-} \mathrm{SiO}_{2}$ dalam bentuk tablet. Sampel ditimbang menggunakan neraca digital untuk mendapatkan nilai berat keringnya $(\mathrm{Wp})$. Selanjutnya sampel 
disintering suhu $500{ }^{0} \mathrm{C}$ selam 1 jam dan ditimbang berat bakarnya (Wb). Tahap selanjutnya sampel direndam dalam air selama 48 jam. Setelah 48 jam sampel dikeluarkan dan ditimbang untuk mendapatkan nilai berat bakar jenuh (Wbj). Besarnya nilai porositas diketahui dengan menggunakan Persamaan 2.

$$
P=\frac{w_{b j}-w_{b}}{w_{p}} \times 100 \%
$$

\section{Hasil dan Pembahasan}

\subsection{Hidroksiapatit}

Pola XRD hasil sintesis HA yang telah dianalisis meng-gunakan highscore disajikan pada Gambar 1. Dengan menggunakan software PCW, diketahui pula nilai parameter kisi dan ukuran butir HA. Besarnya nilai parameter kisi HA adalah $\mathrm{a}=\mathrm{b}=9.4594$ dan $\mathrm{c}=6.8638$ dengan nilai $\mathrm{Rp}=14.24$, $R w p=18.03$ dan Rexp=0.87, sedangkan ukuran kristal yang diperoleh adalah $22.5 \mathrm{~nm}$.

Dari data XRD diketahui juga besarnya derajat kristalinitas HA. Derajat kristalinitas dicari dengan melakukan fitting background dan amorf menggunakan software fullprof. Selanjutnya untuk mengetahui luas background total dan luas amorf dilakukan perhitungan menggunakan software origin pro 8. Derajat kristalinitas dihitung dengan menggunakan Persamaan 3 sebagai berikut.

$$
\%=\frac{\text { Luas Kristalin }}{\text { Luas Kristalin }+ \text { Luas Amorf }} \times 100 \%
$$

Dari hasil perhitungan besarnya derajat kristalinitas HA adalah $74,1 \%$.

Karakterisasi morfologi HA dilakukan dengan menggunakan SEM Merk FEI Type Inspect-S50. Gambar 2 menunjukkan morfologi dari HA.

Selain morfologi, dengan menggunakan SEM-EDX diketahui pula $\mathrm{Ca} / \mathrm{P}$ dari $\mathrm{HA} . \mathrm{Ca} / \mathrm{P}$ merupakan perbandingan atom $\mathrm{Ca}$ dan atom $\mathrm{P}$ dalam senyawa HA. Hasil dari penelitian menunjukkan besarnya nilai rasio $\mathrm{Ca} / \mathrm{P}$ adalah 1,46 . $\mathrm{Ca} / \mathrm{P}$ yang diperoleh dalam penelitian ini lebih rendah dari teori yang ada yaitu sebesar 1,67. Hal ini dimungkinkan karena tidak homogenya fasa-fasa yang terdapat dalam endapan hasil sintesis.

\subsection{Nanokomposit $\mathrm{HA}-\mathrm{SiO}_{2}$}

Pola perbandingan HA murni dan komposit ditunjukkan pada Gambar 3. Berdasarkan Gambar 3 diketahui bahwa adanya penambahan nano $\mathrm{SiO}_{2}$ tidak mempengaruhi fasa dari hidroksiapatit dengan kata lain puncak-puncak dari $\mathrm{SiO}_{2}$ tidak terlihat secara jelas. Hal ini dikarenakan nano $\mathrm{SiO}_{2}$ yang ditambahkan bersifat amorf.

Berdasarkan Gambar 4 diketahui bahwa penambahan nanosilika tidak mempengaruhi ukuran butir dari komposit. Rata-rata ukuran butir komposit adalah kurang dari $100 \mathrm{~nm}$. Hal ini dikarenakan pada saat sintesis dari ketiga komposit diberikan perlakuan yang sama.

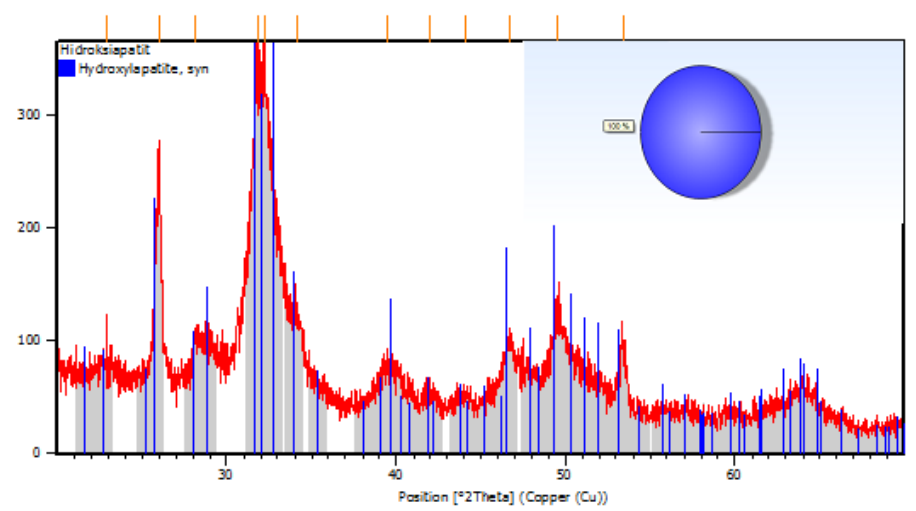

Gambar 1. Pola XRD HA analisis highscores 


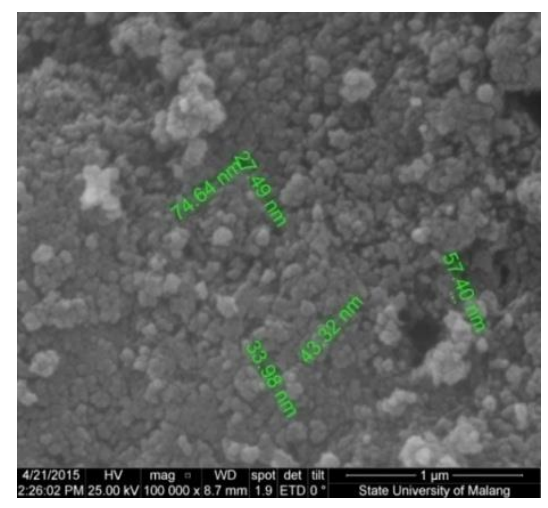

Gambar 2. Morfologi HA Hasil SEM

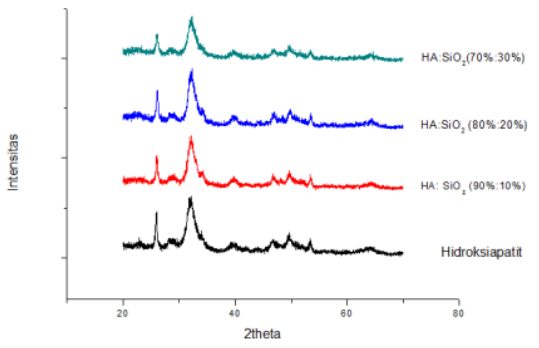

Gambar 3. Perbandingan Pola XRD HA Murni dan Komposit
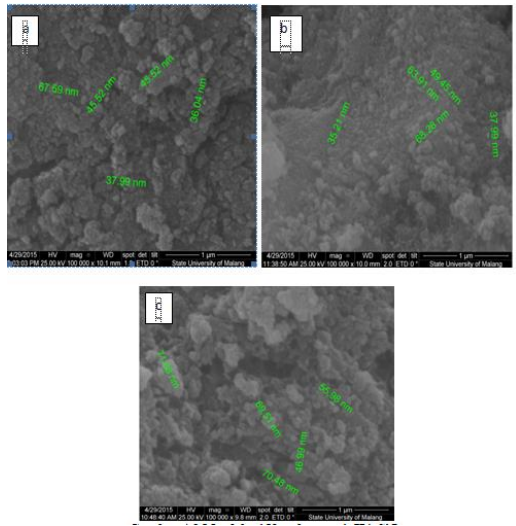

Gambar 4. Morfologi nanokomposit $\mathrm{HA}-\mathrm{SiO}_{2}$

\subsection{Uji Posoritas Nanokomposit $\mathrm{HA}-\mathrm{SiO}_{2}$}

Pengujian porositas dilakukan untuk mengetahui pengaruh besarnya nanosilika yang mengisi rongga kecil HA. Pengaruh penambahan nanosilika ditunjukkan pada Gambar 5.

Berdasarkan Gambar 5 disimpulkan bahwa penambahan nanosilika dapat menurunkan porositas HA. Penambahan nanosilika pada dasarnya adalah menyisipkan nanopartikel ke dalam pori-pori HA sehingga mereduksi mobilitas dari HA. Susunan partikel HA akan menjadi lebih rapat dan jarak antar partikel yang lebih dekat, akibatnya interaksi antar partikel akan menjadi lebih kuat. Selain itu, ukuran nanosilika yang kecil menyebabkan luas muka interaksi semakin besar akibatnya interaksi antar partikel semakin banyak. 


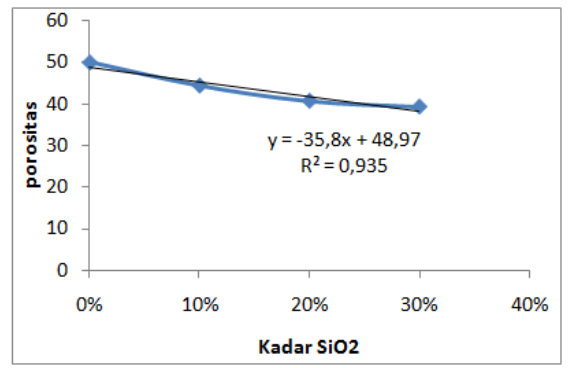

Gambar 5. Grafik Hubungan Penambahan Nanosilika terhadap Porositas

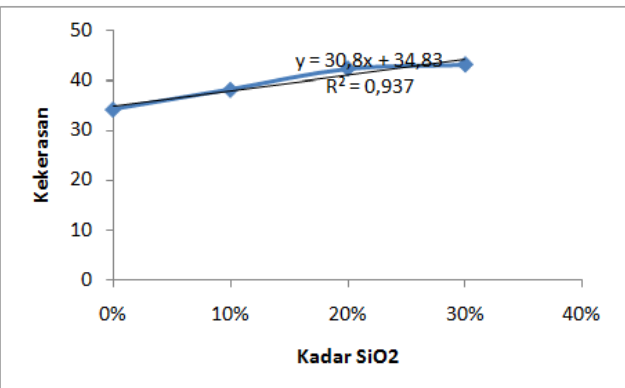

Gambar 6. Grafik pengaruh komposisi nanosilika terhadap kekerasan komposit $\mathrm{HA}-\mathrm{SiO}_{2}$

\subsection{Kekerasan Nanokomposit $\mathrm{HA}-\mathrm{SiO}_{2}$}

Gambar 6 menunjukkan adanya pengaruh komposisi nanosilika pada vikerrs hardnes. Berdasarkan Gambar 6, bahwa besanya komposisi nanosilika memberikan pengaruh pada tingkat kekerasan nanokomposit $\mathrm{HA}_{-} \mathrm{SiO}_{2}$. Sesuai dengan penelitian yang dilakukan oleh Rahman (2014) dan Liu (2013) bahwa sifat mekanik HA meningkat seiring penambahan $\mathrm{SiO}_{2}$. Hal ini berkaitan dengan penambahan nanosilika dapat menurunkan porositas dari nanokomposit $\mathrm{HA}-\mathrm{SiO}_{2}$. Porositas akan menurun menyebabkan jarak antar partikel semakin dekat. Hal ini berakibat ketika nanokomposit diberikan gaya dan tekanan dari luar maka kekerasannya akan meningkat. Dari hasil uji kekerasan, besarnya nilai kekerasan sesuai dengan nilai kekerasan pada human teeth dentin yaitu berkisar 0.28 0.8 Gpa [6].

\section{Simpulan dan Saran}

Hidroksiapatit telah berhasil disintesis menggunakan ba-han dasar batu onyx. Hasil analisis High Score menunjukkan HA yang terbentuk adalah $100 \%$. Hidroksiapatit yang dihasilkan dengan metode kopresipitasi berukuran nanometer yaitu $22.5 \mathrm{~nm}$ dengan rasio $\mathrm{Ca} / \mathrm{P}$ sebesar 1.46 . Selain itu besarnya derajat kristalinitas dari HA sebesar $22.6 \%$.

Penambahan nanosilika akan berpengaruh pada porositas HA. Semakin banyak nanosilika maka porositas dari HA akan menurun. Hal ini dikarenakan nanosilika berfungsi sebagai filler yang mengisi ruang kosong dari HA.

Nilai kekerasan nanokomposit $\mathrm{HA}-\mathrm{SiO} 2$ juga dipengaruhi oleh penambahan nanosilika, semakin banyak nanosilika maka nilai kekerasannya semakin besar. Hal ini berkaitan dengan kesimpulan pada poin 2 yang menyatakan bahwa semakin banyak nanosilika yang ditambahkan, maka porositas akan menurun. Dengan menurunnya porositas maka kekerasan nanokomposit akan meningkat.

\section{Daftar Rujukan}

[1] Bhattacharya (2014). Study on Structural, Mechanical and Functional Properties of Polyester Silica Nanocomposite Fabric. Int. J. Pure Appl. Sci. Technol., 21(1) (2014), pp. 43-52

[2] D. W. Callister (2010). Fundamental of Materials Science and engineering. The University of Utah: Department of Metallurgical Engineering.

[3] Chiara (2012). Nanostructured Biomaterials for Tissue Engineered Bone Tissue Reconstruction. Int. J. Mol. Sci. 2012, 13, 737-757 
[4] Darwis (2008). Sintesis Dan Karakterisasi Komposit Hidroksiapatit (Ha) Sebagai Graft Tulang Sintetik. Jurnal Ilmiah Aplikasi Isotop dan Radiasi A Scientific Journal for The Applications of Isotopes and Radiation. Vol. 4 No. 2 Desember 2008

[5] M. Ibrahim (2011). Chemical characterization of some substituted hydroxyapatites. Chemistry Central Journal , 5:74

[6] T. Kokubo (2008). Bioceramics and Their Clinical Applications.Cambrigde England dan Boca Raton. USA: Woodhead Publishing LimiteddanCRC Press LLC

[7] F. Kusumawati (2014). Pengaruh Lama Sonikasi Pada Sintesis Nano Hidroksiapatit Dari Batuan Calcite Druju Malang Dengan Metode.

[8] Liu (2013). Effect of Filler Ratio on Properties of Nano-hydroxyapatite/ $\mathrm{SiO}_{2}$ Based Bioactive Dental Resin Composites. Materials Science Forum. Vols. 745-746 (2013) pp 466-472

[9] Munasir (2012). Uji Xrd Dan Xrf Pada Bahan Meneral Batuan Dan Pasir) Sebagai Sumber Material Cerdas (CaCO3 Dan $\mathrm{SiO}_{2}$ ). Jurnal Penelitian Fisika dan Aplikasinya (JPFA). Vol 2 No1

[10] Munasir (2013). Pengaruh Molaritas Naoh Pada Sintesis Nanosilika Berbasis Pasir Bancar Tuban. Jurnal Penelitian Fisika Dan Aplikasinya (JPFA). Vol 3 No 2, Nopember 2013 ISSN: 2087-9946

[11] Ningsih (2014). Sintesis Hidroksiapatit Dari Cangkang Kerang Kepah (Polymesoda Erosa) Dengan Variasi Waktu Pengadukan. JKK,Tahun 2014,Volum 3(1), halaman 22-26

[12] J. Park (2008). Bioceramics Properties, Characterizations, and Applications. USA : University of Iowa

[13] Rahman (2014). One-pot synthesis of hydroxyapatite-silica nanopowder composite for hardness enhancement of glass ionomer cement (GIC). Bull. Mater. Sci., 37, 213-219.

[14] A. Rahmawati, N. Z. Ilmi, H. Seyawan, Affandi, Samsudin. 2012. Sintesis Hydroxiapatite Berukuran Nano dengan Metode Elektrokimia Menggnakan Pulse Direct Current (Pdc) sebagai Bioimplan Tulang dan Gigi. Jurnal Teknik Pomfits. 1, 1-4. 